\title{
CHALLENGES IN IMPLEMENTING TAXES ON E-COMMERCE TRANSACTIONS IN MALAYSIA
}

\author{
MOHD RIZAL PALIL 1 \\ HOD BIN AMIN ${ }^{2}$ \\ SITI ZAIDAH TURMIN ${ }^{3}$
}

${ }^{1}$ Faculty of Economics and Management, Universiti Kebangsaan Malaysia, 43600 Bangi, Selangor, Malaysia

${ }^{2}$ School of Management and Social Science, Kolej Yayasan Pelajaran Johor, 81900 Kota Tinggi, Johor, Malaysia

${ }^{3}$ School of Business and Economics, Universiti Putra Malaysia, 43400 UPM Serdang,, Selangor

mr_pali@ukm.edu.my, hod@kypj.edu.my, zaidah@upm.edu.my

\begin{abstract}
Electronic commercial transactions are growing rapidly, thereby causing unease among conventional traders who believe that the taxation system is unfair to them because of loopholes that cause e-commerce traders to avoid taxes. The government's perspective is that e-traders cause losses in taxes that could otherwise increase the country's revenue and harmonize the tax system among all traders, whether e-commerce or conventional. Various views have been expressed on the implications of e-commerce; some argue that e-commerce improves the tax system, whereas others believe that the tax system was designed prior to the emergence of e-commerce, thereby creating problems in Malaysia. Therefore, this study investigates the problems posed by e-commerce, especially in identifying challenges in taxation. Based on systematic literature highlights, 6 major challenges have been identified, consisting of 22 items in tax implementation for e-commerce in Malaysia. A quantitative research approach has been used to ensure generalization of opinions on tax implementation challenges that are appropriate to the context of taxation in the country. Based on the feedback received by 73 respondents consisting of officers involved in the Malaysian tax system, the reflective-formative hierarchical model was analyzed using a structural equation model through SmartPLS software to address the tax implementation challenges for e-commerce. This study is regarded as beneficial for the parties involved, especially the Inland Revenue Board, in designing efficient and systematic tax rules and guidelines on e-commerce so that potential tax sources can be identified and losses can be reduced.
\end{abstract}

Keywords: E-commerce transactions, taxes, taxation issues, Malaysia

\section{INTRODUCTION}

Rapid development of information technology has enabled people to enjoy a more efficient lifestyle. Television, radio, computers, and the internet can provide real-time information that transcends geographical boundaries. The widespread use of the Internet can solve problems in exchanging data across borders at any time. As a result, almost everything can be accessed with a single click on an electronic device. This situation has resulted in a society where most activities can be performed in the blink of an eye. E-commerce transactions are among the most common activities at present. The Inland Revenue Board of Malaysia (IRB, 2019) has defined these transactions as any sale or purchase of goods or 
services conducted through any network with methods specifically designed for receiving and placing orders. Goods and services are ordered through the stated method, but payment and delivery are not conducted online. E-commerce transactions can take place between businesses, households, individuals, government agencies, and public and private organizations. The development of IT goes with the development of e-commerce transactions. The number of internet users in Malaysia shows a positive correlation with the number of online sellers. Among 16 million Malaysians, 50\% use mobile phones, and $62 \%$ of mobile phone users shop online (Hadri, 2018).

Along with the population increase in Malaysia, the number of e-commerce users is also expected to grow in the future. This fact motivates business players to equip their grocery stores with e-forms to ensure the continuity of operations and yield good results in the stock market. Revenue through e-commerce transactions recorded a total value of RM447.8 billion in 2017 compared with RM398.2 billion in 2016, accounting for an annual growth rate of $6.0 \%$. Meanwhile, e-commerce transaction expenses recorded a value of RM228.8 billion in 2017 compared with RM195.1 billion in 2016, representing an annual growth rate of $8.3 \%$. The main contributors to e-commerce revenue and expenditure in Malaysia are the manufacturing sector with RM287.5 billion and RM179.5 billion, respectively, according to data from the Department of Statistics (2019). In Indonesia, ecommerce can add US $\$ 150$ billion a year to gross national product in 2025 (Abraham, 2016). E-commerce trade continues to change the method of business and trade both in the global and domestic economies.

\section{Statement of Problem: Tax Dilemma on E- Commerce Business}

Based on data released by Bank Negara Malaysia from January to August 2017, a total of 1.4 million cashless or e-money transactions worth RM10.6 billion were conducted in Malaysia during the aforementioned period. According to the IRB, in the distribution of Guidelines on Taxation of Electronic Commerce in paragraph 4 of the Scope of Tax Liability for Business, no specific provision on e-commerce transactions is included in the Income Tax Act of 1967. Therefore, general provisions and translations to the 1967 ITA were adopted. In the context of ecommerce, specific business activities that can be considered in determining business operations include content sourcing, purchase of goods, sales promotion and advertising, updating and maintenance of websites, downloading and uploading content, and others. Although the number of transactions is more than a million, no tax revenue can be collected on these e-commerce activities. This condition is unfair to salespeople who operate physical businesses and have to pay taxes compared with those who trade on online platforms. The development of e-commerce activities has also caused issues, especially in taxation and allocations, concerning the impact on tax collection in Malaysia. Agrawal (2014) explains that the growth of e-commerce transactions in India leads to the need for special tax allocations to reduce tax evasion and emphasis on ecommerce as a new way for traditional businesses to avoid taxes (Fauzana, 2018).

In Malaysia, the main problem in ecommerce transactions is the inability of the IRB to identify the transactions and payments conducted virtually. This situation causes the government to lose indirect taxes, such as import taxes, if transactions are conducted across borders. Furthermore, if the transaction is done in Malaysia, then it is difficult for a personrun business to be taxed, especially in the case of individuals who are not registered with the Companies Commission of Malaysia (Suruhanjaya Syarikat Malaysia). Furthermore, online merchants, through social sites such as Facebook and Instagram, cannot be taxed even 
though their monthly income is eligible for tax. Therefore, this matter should be addressed. To boost the country's tax collection, the IRB needs to formulate a new tax mechanism to impose taxes on groups that conduct business transactions online.

\section{E-Commerce Contribution and Performance Statistics in Malaysia}

A publication on the Malaysian Digital Economy 2018 is obtained from the Information and Technology Communication Satellite Account (ITCSA) 2018, where this publication provides digital economic statistics for the needs of government agencies, economists, private sector, and individuals to plan and formulate policies, economic analysis, and projections, as well as assist in business development planning. Based on the ICTSA 2018 report, the contribution of the digital sector to the national economy continued to grow to RM267.7 billion in 2018 , accounting for $6.9 \%$ growth $(9.8 \%$ in 2017). The information and communication technology (ICT) sector contributed $18.5 \%$ to gross domestic product (GDP), comprising gross value-added for the ICT industry (12.6\%) and ecommerce for non-ICT industries (5.9\%). In 2018, the GDP of the ICT industry increased to RM182.4 billion, accounting for $6.1 \%$ growth. The ICT services industry dominates the GDP of ICT with a contribution of $43.2 \%$, followed by the ICT manufacturing at $34.1 \%$. Telecommunication services are a major driver of ICT services. The manufacture of ICT is supported by electronic components and boards, communication equipment, and consumer electronics.

Revenue through e-commerce transactions recorded a total value of RM 447.8 billion in 2017 compared with RM 398.2 billion in 2015 with an annual growth rate of $6.0 \%$. Meanwhile, e-commerce transaction expenses recorded a value of RM 228.8 billion in 2017 compared with RM 195.1 billion in 2015, accounting for an annual growth rate of $8.3 \%$. The main contributors to e-commerce revenue and expenditure were the manufacturing sectors with RM287.5 billion and RM179.5 billion, respectively.

\section{Objectives of the Study}

Various views have been expressed on the implications of e-commerce. Some argue that e-commerce improves the tax system, while others believe that the tax system in Malaysia was designed in an era when e-commerce did not exist, thereby causing problems in the tax system. Thus, the objective of the present study is to investigate the problems posed by $\mathrm{e}$ commerce, especially in identifying obstacles and challenges faced by the authorities, especially the IRB, in e-commerce tax implementation. As constraints in strengthening the tax system in Malaysia, these challenges have to be identified and further confirmed through empirical studies.

\section{Problems Related to E-Commerce Taxation}

Many issues have been observed and debated on taxation related to e-commerce. This subject involves several streams of thought, but limited studies have been conducted on this matter. In general, many believe that ecommerce poses a problem in tax law (Vohra, 2004). Existing tax laws only cover transactions limited to conventional trade where physical transactions are easily tracked by tax collectors. However, the same principle does not apply to e-commerce transactions based on several factors. For example, a consideration is the principle of permanent establishment (PE) location, which have been used to determine whether a country is categorized as a resource and should impose a tax on profits earned from foreign business based on the principle of physical presence. Apart from PE, important tax issues have to be considered, such as double deduction, along with principles that lead to tax avoidance and evasion (Borkowski, 2002).

Recognizing the importance of taxrelated problems on e-commerce, developed countries such as the United States, the United 
Kingdom, France, Germany, and Australia have published e-commerce policy statements (Foley \& Khoo, 2000). Typically, developed countries are aware of the impact of e-commerce on taxpayers and have taken several ways to protect their tax collection. However, differences of opinion exist among policymakers, especially because policies adopted by these countries differ slightly due to their varying social, political, and ideological situations.

In Hong Kong, a questionnaire was distributed to study the potential international problems posed by e-commerce. The study found that e-commerce poses problems in tax administration, double deductions, and tax evasion. Interestingly, studies show that tax evasion is the highest potential tax problem that has been identified in relation to e-commerce (Davis \& Chan, 2000). Other issues identified were double deduction and tax administration, while tax evasion was considered the smallest problem. Considering the impact of e-commerce on tax authorities, the Hong Kong Society of Accountants has set up a Tax System Inspection Committee to investigate matters related to its taxation system. This committee was formed to identify taxation areas affected by e-commerce, how e-commerce transactions should be taxed, and how the PE can be strengthened to act as a strong legislation that brings electronically based revenue to net tax and curb activities that lead to the loss of tax revenue.

Therefore, the Organization for Economic Co-operation and Development (OECD) has launched a tax model for ecommerce, which is now used as a benchmark in many countries including Malaysia (Scally, 2002). The OECD Electronic Trade and Taxation Conference held in October 1998 reached a consensus on various issues, which resulted in a joint declaration on taxation and e-commerce. In addition, the Ottawa Conference (year) concluded that governments and businesses should work together in implementing a tax framework for e-commerce so that the full potential of new technologies can be realized. Conference representatives see the great potential of new technologies in simplifying the taxation system and improving taxpayer services that can be guided by the same principles used in the current tax system. As a result, in October 1999, the OECD Working Group on Tax Conventions proposed the adoption of $\mathrm{PE}$ definitions for e-commerce transactions, which have been used by many countries as a guide to address issues related to PE in their territories.

E-commerce transactions have grown exponentially, thereby causing inconvenience for conventional persons who operate businesses as the taxation system is considered unfair due to loopholes that enable e-commerce operators to avoid taxes. The government's perspective also considers this group as a loss to the government in collecting taxes that can otherwise increase the country's revenue and harmonize the tax system among person-run businesses, whether e-commerce or conventional. Therefore, this study investigates the problems posed by e-commerce, especially in identifying barriers and challenges in taxation.

\section{E-commerce-related Tax Systems in Malaysia}

Differences in tax practice are generally due to cultural, social, and political factors. Regardless of these differences, most tax practices are designed with basic elements of judgment such as neutrality, certainty, and fairness. Malaysia, like other countries, uses a balanced tax system where all elements have been considered. The country's taxation system is regional in nature, which implements a resource-based approach to impose income tax. According to the practice of resource-based systems in Malaysia, income is taxable if it is earned in the country or received in the country from abroad. A determining factor in tax generation is the principle of income source, that is, the place where the contract is negotiated or where the contract is settled, and identifying 
whether the business operation is conducted in Malaysia.

To date, the IRB has not issued specific guidelines on e-commerce tax. The increase in trade volume from e-commerce activities must be monitored. Therefore, a fair set of tax systems for governments and taxpayers needs to be initiated. It is recommended that the national tax system be introduced to reduce the imbalance of tax collection from e-commerce activities. In the future, e-commerce and the internet are no longer extraordinary to taxpayers and have become a habit of doing business. Therefore, a fair tax system needs to be established. Thus, the government should take further steps to meet the needs of the current tax system by considering technological changes to avoid losing revenue from taxes.

The basis for the strengthening of the tax system in Malaysia requires a study to identify the constraints and challenges and create and implement e-commerce taxes. This study will consider the matter to help the parties involved, especially the IRB, to identify challenges that jeopardize efforts to strengthen the taxation system in the country. The IRB also needs to be prepared in advance so that it will have a stable e-commerce tax system that can handle most of the transactions through ecommerce.

\section{Theory Related to E-commerce Tax Implementation Challenges}

This study adheres to the theory of optimal tax standards (Mankiw, Weinzierl, \& Yagan, 2009), which states that the tax system should be formed based on the system's ability to maximize the tax function itself but should look at constraints or challenges in the tax implementation. The basis for this theory is also guided by the Mirrlees framework (1971). This framework emphasizes the relationship between tax policymakers and taxpayers in maximizing the tax function itself. The optimal tax standard theory also clearly states that any tax implementation should be guided by the problems that will arise which in turn becomes a challenge to the tax policy makers as well as the taxpayers themselves. Thus, this study adapts this theory to identify the challenges that will be faced by the authorities, especially the IRB, in implementing taxes on e-commerce to improve the tax function in Malaysia to be more organized and systematic. Any decision from the policy makers in choosing the tax system should maximize the well-being of the taxpayers and consider the consensus from the consumer perspective as they should be reminded that they will respond through a positive or negative response to the tax system imposed on them.

\section{Challenges of Tax Implementation Based on Past Studies}

Through previous studies, six main challenges consisting of 22 challenge items have been submitted by researchers. (Suntoro \& Tjen, C. 2017; Patel, = 2014; Mohd Hanefah, Othman, \& Hassan, 2006; Low, Kabasunakatuba \& Sharma, 2013; Chen \& Wang 2010, 2005) and collected in this study.

The first major challenge identified by previous researchers was the difficulty in identifying taxpayers (Suntoro \& Tjen, 2017; Patel, 2014; Low, Kabasunakatuba \& Sharma, 2013; Chen \& Wang 2010; Pinto, 2005). Five items of challenge exist, namely, no provision for tax registration, unclear criteria, absence of information, duplication of information, and absence of cooperation from taxpayers. For the first item, taxpayers in Malaysia consist of various taxpayers of different ages and qualifications, which allows them not to register for e-taxation at the IRB, especially those who are old and have no formal education. There is no provision from any act in the IRB that requires taxpayers to register e-taxation in the IRB and is not fined if the taxpayer does not register etaxation (Suntoro \& Tjen, 2017). For the second item, the classification, criteria, and types of taxable e-commerce products are unclear and dubious. The required information encourages taxpayers to avoid filling in the required 
information. Taxpayers are still unaware that taxes are levied on e-commerce transactions. For the third item, the IRB finds it difficult to identify and obtain evidence of business transactions for person-run businesses conducting business abroad because of distance and different applicable laws in each country. For the fourth item, taxpayer information (such as contract number, taxpayer phone number, identity card number, tax reference number, and business address) of one individual overlaps with that of another. For the last item, the major challenge is that the taxpayer is difficult to contact to complete the proof of ecommerce transactions. This is particularly true for taxpayers who live in remote areas and have difficulty providing e-commerce transaction information for their IRB e-files.

The second major challenge identified by previous researchers is incomplete existing information (Suntoro \& Tjen, 2017; Pinto, 2005), which are related to inaccuracy, weakness in collecting information, and lack of tax collection officers. For the first item, the information on ecommerce transactions provided by the taxpayer is inaccurate and dubious. This happens when the taxpayer does not state the overall income from the e-commerce transaction. For the second item, the existing e-filing system is not customer-friendly enough to collect e-commerce transaction information, especially for older and inexperienced taxpayers who use the system provided by IRB. The third item revolves around the lack of qualified, experienced, and customerfriendly IRB staff to collect e-commerce business information from taxpayers. The staff at the IRB needs to be increased to collect e-commerce business information from taxpayers.

The third major challenge encountered by previous researchers is the difficulty in identifying e-commerce products (Suntoro, A. A., \& Tjen, C. 2017; Patel, S. H., 2014; Low, Kabasunakatuba \& Sharma, 2013). Four items are included in this main challenge: difficulty experienced by officers in identifying e- commerce products, unclear product determination criteria, incomplete product information, and variety of e-commerce products that cause difficulty in tracking such products. For the first item, the entry of new and untrained officers pose issues in determine which products are being sold physically or online. Experienced officers are more adept at determining products sold electronically. The second item is the difficulty in determining whether a sales product is charged and not taxed due to unclear criteria for each of those products. Numerous criteria in terms of price, delivery method, and payment method are used to describe products available in Malaysia. The third item is that the taxpayer does not fully cooperate in providing complete product information such as actual sales volume. Taxpayers always refrain from disclosing overall sales, especially e-commerce sales information. Taxpayers have many types of products that need to be updated from time to time, but they lack time to update these new products on the IRB system; thus, taxpayers are likely to hide new product information.

The fourth major challenge identified by previous researchers is the lack of an audit tracking system (Suntoro \& Tjen, 2017; Chen \& Wang, 2010; Mohd Hanefah, Othman, \& Hassan, 2006; Pinto, 2005). Three items included in this major challenge are unclear audit feature criteria, difficulty in obtaining evidence and constraints in the authority of the officer responsible for collecting taxes. For the first item, the transaction criteria in determining the audit characteristics of e-commerce products are unclear and misleading, thereby resulting in the impossibility of audit determination for the entire e-commerce product. Clear criteria include sales value level criteria and types of ecommerce business activities for taxpayers. The second challenge is the difficulty experienced by officers in obtaining evidence and information on e-commerce transactions during the audit session. The reason is that the taxpayer does not carefully store the proof of transaction, which 
results in loss of business documents, and the reluctance of the taxpayer to disclose the value of the transaction. Furthermore, depending on their rank, officers have different degrees of authority to conduct audit tracking. Top officials have limited time to perform audit tracking that requires high-level skills and experience. Due to certain factors, some information is also inaccessible to officers when conducting audits.

The fifth major challenge is the lack of control in the tax system (Patel, 2014; Suntoro \& Tjen, 2017; Li, 2000). Three items are included in this major challenge, namely, the limited tax system infrastructure, various functions of the ecommerce system, and manual access. For the first item, the tax system infrastructure are inadequate and outdated software and equipment used at the IRB office. The system cannot handle a large volume of information and requires time to download documents quickly and accurately. The second item is the ecommerce system, which shows a variety of menus and methods used by consumers in Malaysia and around the world. IRB officials are unable to master the use of all the different $e$ commerce systems in each organization. Proof of transaction can only be obtained from the ecommerce system. The third item is that the small-scale person run business find it difficult to make tax payments using electronic platforms, causing the burden of IRB officers to increase to ensure that tax payments by small-scale person run business are timely.
The sixth major challenge identified by previous researchers is the method of tax payment by consumers (Suntoro \& Tjen, 2017; Pinto, 2005). Four items are included in this major challenge, namely, difficulty in making payments, system transparency as a concern for person-run businesses, information hiding by person-run businesses, and tax officers' inability to access payment transactions. For the first item, the inefficient payment system causes difficulty for person-run businesses to make tax payments due to time constraints during the transaction. Businesses operated by aged persons also have difficulty in conducting transactions electronically. Second, e-payments store purchases, sales and stock information transparently and accurately, and can help the IRB identify sales, purchases, and other expenses of person-run businesses. Person-run businesses would be concerned if the information is known by the IRB, which would require the businesses to pay higher taxes. Third, e-commerce platforms that require passwords that cannot be accessed by officers further cause difficulty for IRB officers to identify the proof of payment made by person-run businesses. Some countries do not allow IRB officials to access e-commerce platforms by giving various reasons.

In conclusion, the six main challenges consisting of 22 challenges discussed by previous researchers cause difficulty for the IRB in implementing e-commerce taxes in Malaysia, as summarized in Table 1.

Table 1 Tax Implementation Challenges in E-Commerce

\begin{tabular}{ccl}
\hline VARIABLE & REFERENCE & \multicolumn{1}{c}{ ITEM } \\
\hline Taxpayer Identification & $\begin{array}{c}\text { (Suntoro \& Tjen, 2017; } \\
\text { Patel, 2014; Low, } \\
\text { Kabasunakatuba \& Sharma, } \\
\text { 2013; Chen \& Wang 2010; Pinto, }\end{array}$ & Absence of rules \\
$2005)$ & Absence of information \\
& Information overlap \\
\hline
\end{tabular}




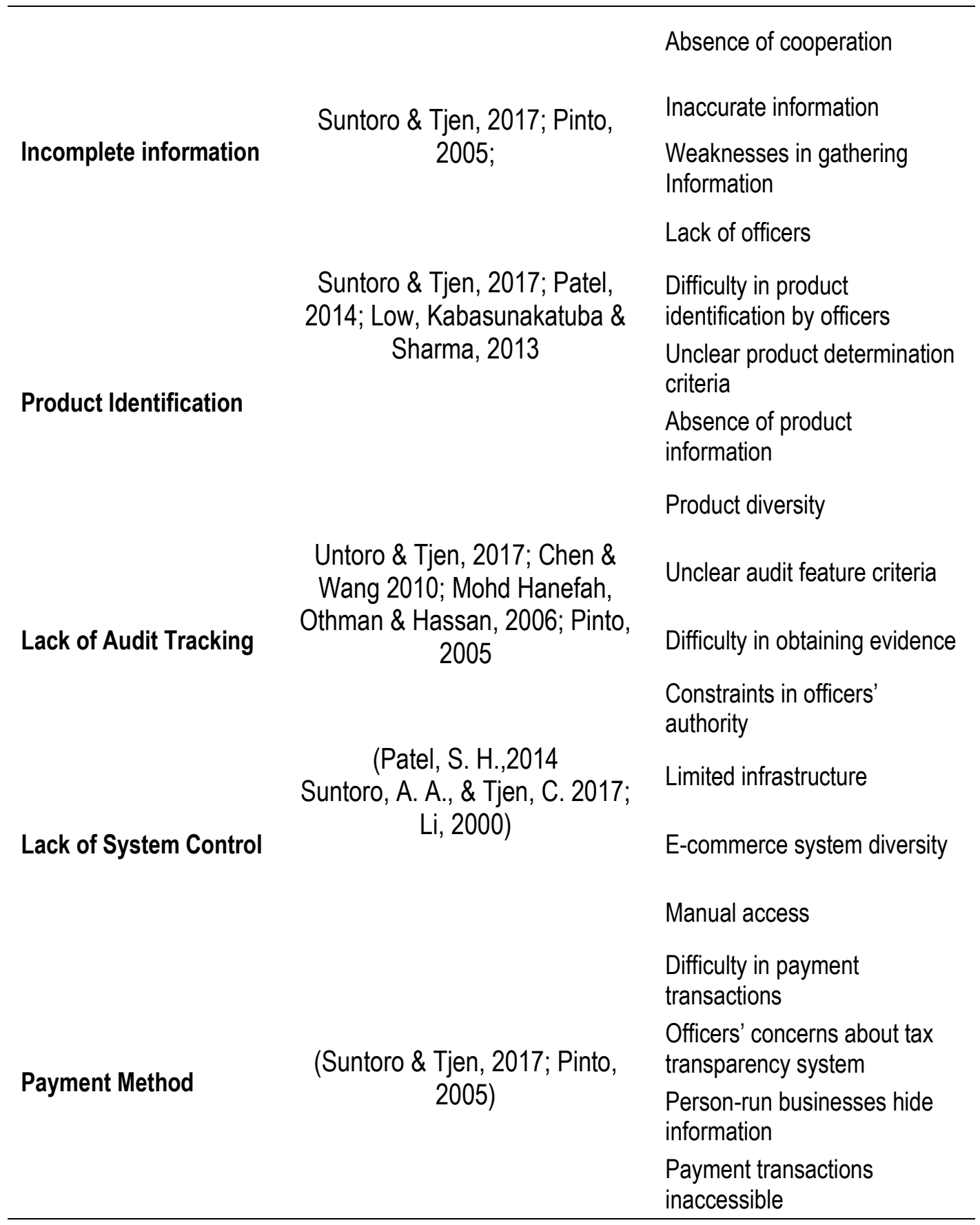

\section{STUDY DESIGN}

This study was conducted among 73 respondents who served as IRB officers. Data were collected using the questionnaire method to obtain information on the challenges faced in collecting taxes on e-commerce transactions by person-run businesses in Malaysia, specifically in the Southern Region (Johor, Melaka, and Negeri Sembilan), Central Region (Kuala Lumpur, Selangor, and Pahang), East Malaysian (Sabah and Sarawak), and Northern Region (Perak, Penang, Kedah, Perlis, Kelantan, and Terengganu). The detailed steps for each 
method, technique, and data analysis are aligned with the research questions and objectives. This study consists of three phases, each describing the research activities conducted. Figure 1 illustrates the flow chart of the research process.
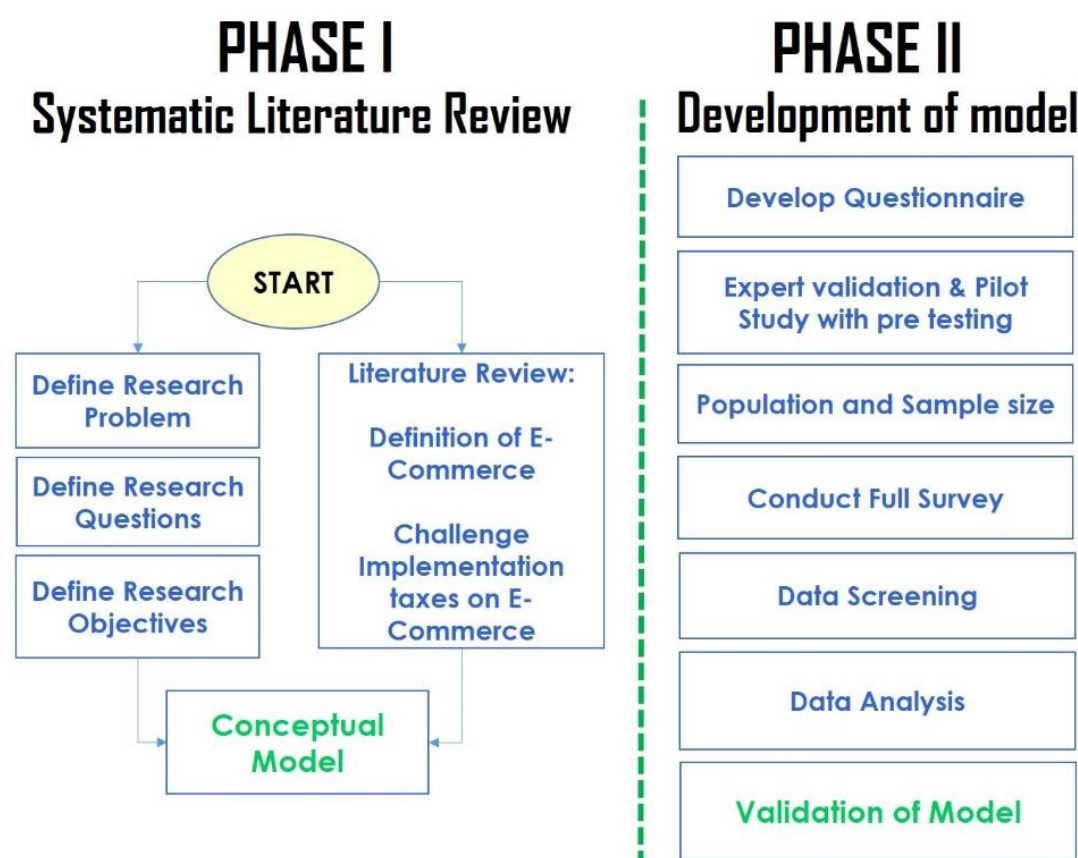

\section{PHASE III \\ Discussion and Conclusion}

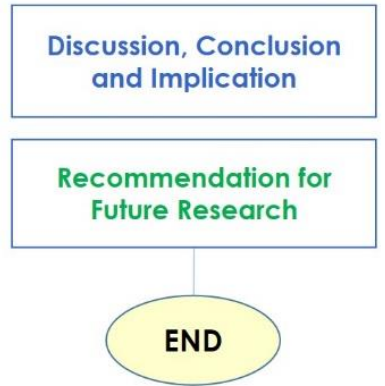

Figure 1 Flowchart of Research Process

Starting with Phase I, this study covers the research background, statement of research problems, statement of research objectives and importance of research explained in detail. The research purpose is to identify the challenges in tax implementation on e-commerce that is gaining ground among person-run businesses in Malaysia. This study is extended with the information needed through the search on previous studies to enable researchers to 
determine the challenges faced by e-commerce tax collectors in Malaysia. Comprehensive information retrieval based on extensive resources and structured search protocols ensure that the required information can be obtained.

Phase II is a critical phase for this study because the results of phase I are used in generating a questionnaire to confirm the challenges faced by the IRB in implementing ecommerce taxes. Two outcomes to be achieved in phase II are the formation of a questionnaire and formation of a list of challenges through PLS-SEM analysis. The questionnaire method is used to collect data on the opinions of respondents who are directly involved in the taxation system in Malaysia (Chang, 2002). Mangione (1995) emphasizes the advantages of questionnaires in collecting data such as the ability to obtain sufficient samples with independent and unbiased studies. Indeed, this method of questionnaire is advantageous to researchers because it can provide time and energy savings and cost effectiveness (Cooper and Schindler, 2003). As stated, the implementation challenges obtained from the literature review should be generalized in the
Malaysian context to answer the research questions through many respondents (Cresswell, 2014). Questionnaires generally begin with the formulation of questions, followed by confirmation of the questionnaire by expert opinion, and determination of the population and sample size. Then, the pilot study is conducted and the final step is administering the questionnaire completely. Two methods are used to channel the questionnaire to the target respondents, namely, through hard copy and through electronic version. Data collection was analyzed using SPSS and PLS-SEM software. Analysis of the second-order hierarchy model based on the evaluation method (Hair et al., 2014) using partial least squares-structural equation modeling (PLS-SEM) was used in this study to measure the challenges faced in implementing tax on e-commerce.

Researchers evaluated the study model by following a two-step process as suggested by Hair et al. (2014). The analysis of the measurement model includes indicator reliability, internal consistency as well as convergent validity and discriminant validity, which aim to assess the reliability and validity of constructs as shown in Figure 2.

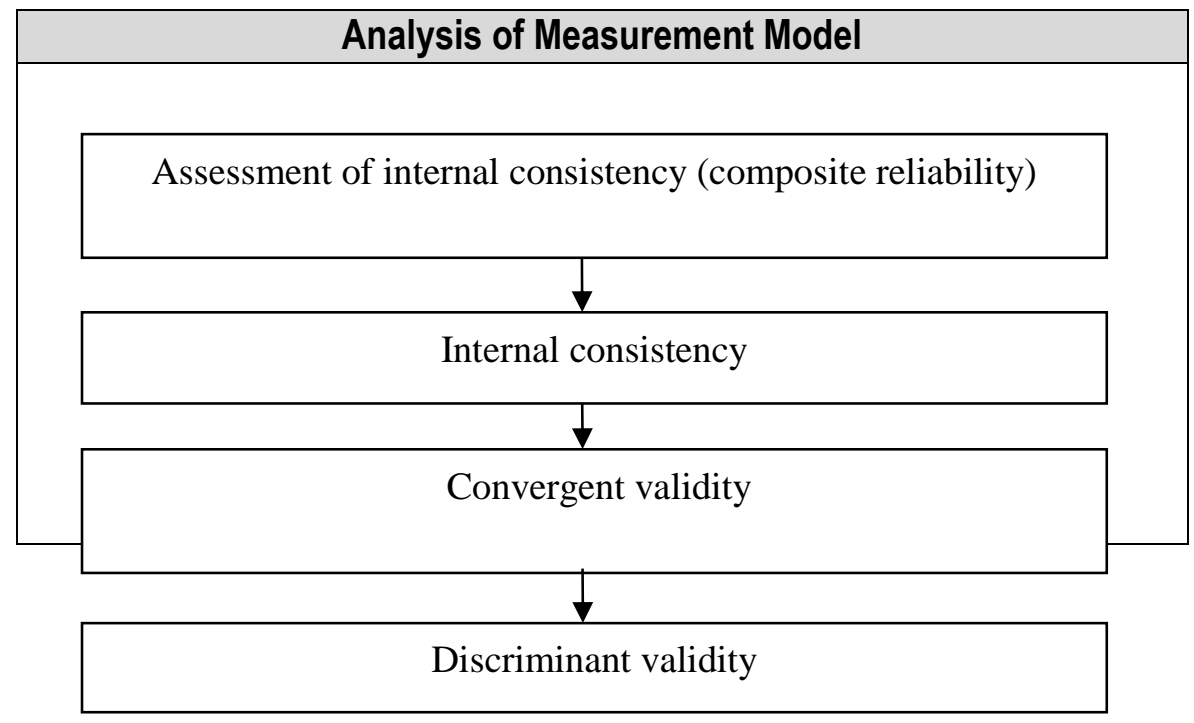

Figure 2 Analysis of Measurement Model 
Finally, Phase III covers two main elements: study conclusions and recommendations for future research. The results of the study obtained through comprehensive analysis are formulated as a whole and discussions for future studies are proposed. Phase III also discusses and interprets the research results based on the objectives and inquiries that have been formulated.

\section{Construction Questionnaire}

The creation of the questionnaire is important for this study because the information that will be used for analysis depends on its content. This condition is emphasized by Cooper and Schindler (2003), who argued that the appearance of the questionnaire is an important element to attract respondents to obtain the desired data. Therefore, the questionnaire should be "friendly" with the respondents. Questionnaires should begin with an introduction to the research and the importance of research so that respondents can understand it (Field, 2009) before they begin to answer questions. To reduce injustice (bias) and confusion among respondents, important terms and concepts should be defined as clearly as possible. This matter is considered by the researcher where each item in the questionnaire is explained as shown in Table 1.

In general, the questionnaire consists of two parts: information on the background and demographics of the respondents, followed by questions related to the challenges faced in ecommerce tax implementation. The information in the questionnaire was presented based on an extensive literature review. Two important elements to be discussed in creating the questionnaire are the instruments used to collect and measure the information as well as the Likert scale for the question. In the first element, as explained by Creswell (2014), five types of instruments have different functions in gathering information or measuring variables. Based on the type of instrument, a demographic form questionnaire was used in part I to collect information about the respondents, while part II uses attitudinal measure (Creswell, 2014), which refers to the level of agreement on tax implementation challenges to e-commerce in Malaysia. The questionnaire in Part I contains questions related to the background of the respondent contains three questions related to basic information such as gender, region where the officer works and the level of position of the respondent. This question is needed to identify if there are differences of opinion on the challenges faced based on these three elements. Part 1 continues with two more questions related to the period of service and period of involvement of officers in the taxation system. This question is needed to identify if these two elements influence the respondents' opinion on the challenges they faced. Part 2 of the questionnaire includes questions related to 22 items classified into 6 main sections based on previous literature review as explained by Suntoro and Tjen (2017), Patel (2014), Low, Kabasunakatuba and Sharma (2013), Chen and Wang (2010), Mohd Hanefah, Othman and Hassan (2006) and Pinto (2005). The questions are designed based on explanations and descriptions by each researcher as described in Figure 1 and the questionnaire can be referred to appendix $A$.

\section{Sample and Population of Study}

Selection of sample size is important to ensure that the study findings can be confirmed accurately as stated by Smola and Bartlett (2001), where the sample size selection is an important element of questionnaire research. Sampling is important to determine enough respondents from the total target population to draw conclusions on the generalization of the study population (Field, 2009). In this study, sample size determination is based on the work of Krejcie and Morgan (1970), as adapted by researchers to determine an adequate sample size as shown in Table 2. 
Table 2 Determination of Sample Size

\begin{tabular}{cc}
\hline POPULATION & SAMPLE \\
\hline 420 & 201 \\
440 & 205 \\
460 & 210 \\
480 & 214 \\
500 & 217 \\
550 & 225 \\
\hline
\end{tabular}

This study uses a quantitative approach that involves questionnaire distribution. The population sample is calculated based on the Krejcie-Morgan table. Based on briefings and information from representatives of the IRB tax department, e-commerce tax collection management is under the Revenue Collection Department, one of the 22 departments of the IRB, as shown in Appendix B. In this department, which includes 476 employees, several divisions have specific functions, including e-commerce tax collection. The number of employees does not include subordinate staff, such as counter staff for each tax collection division at the state level. These 476 respondents are officers who are directly involved in identifying and implementing e-commerce taxation in Malaysia. These respondents consist of three categories: top management, tax executives who are assigned specifically for tax collection operations for individuals and companies conducting ecommerce-based businesses in Malaysia, and support staff involved in the construction and updating of the tax system as well as the data collection related to e-commerce taxes in the IRB organization. Referring to the total population in the Krejcie-Morgan table, only a total of 214 sample questionnaires are required to distribute targeted questionnaires among tax officers in Malaysia.

\section{RESULT}

\section{Confirmatory Factor Analysis}

Structured analysis was performed through verification factor analysis using SPSS version 23.0 and Smart PLS version 3.0. Hair et al. (2014) mentioned that structural equation modeling (SEM) is a multivariate technique that combines aspects of factor analysis and regression that allows researchers to examine simultaneously the relationship between measured and latent variables as well as between latent variables. SEM is a method to measure the model, and analyze the casual relationship between constructs in a structured model based on variance and covariance (Awang, 2014).

Researchers have two options to examine SEM, namely, covariance-based SEM (CB-SEM) and semi-smallest-SEM (PLS). Each technique has its advantages and needs to be adapted according to the study situation so that various objectives can be achieved on the basis of different measurement philosophies (Hair et al., 2014). Many researchers face a dilemma in selecting which approach to use in their modeling analysis. Hair et al. (2014) acknowledge this condition and provide guidelines in selecting between CB-SEM and PLS-SEM based on several factors, including objectives, measurement model specifications, structural modeling, data characterization, and model evaluation. Based on the guidelines presented by Hair et al. (2014), PLS-SEM was selected for use compared with CB-SEM as described in Figure 3. 


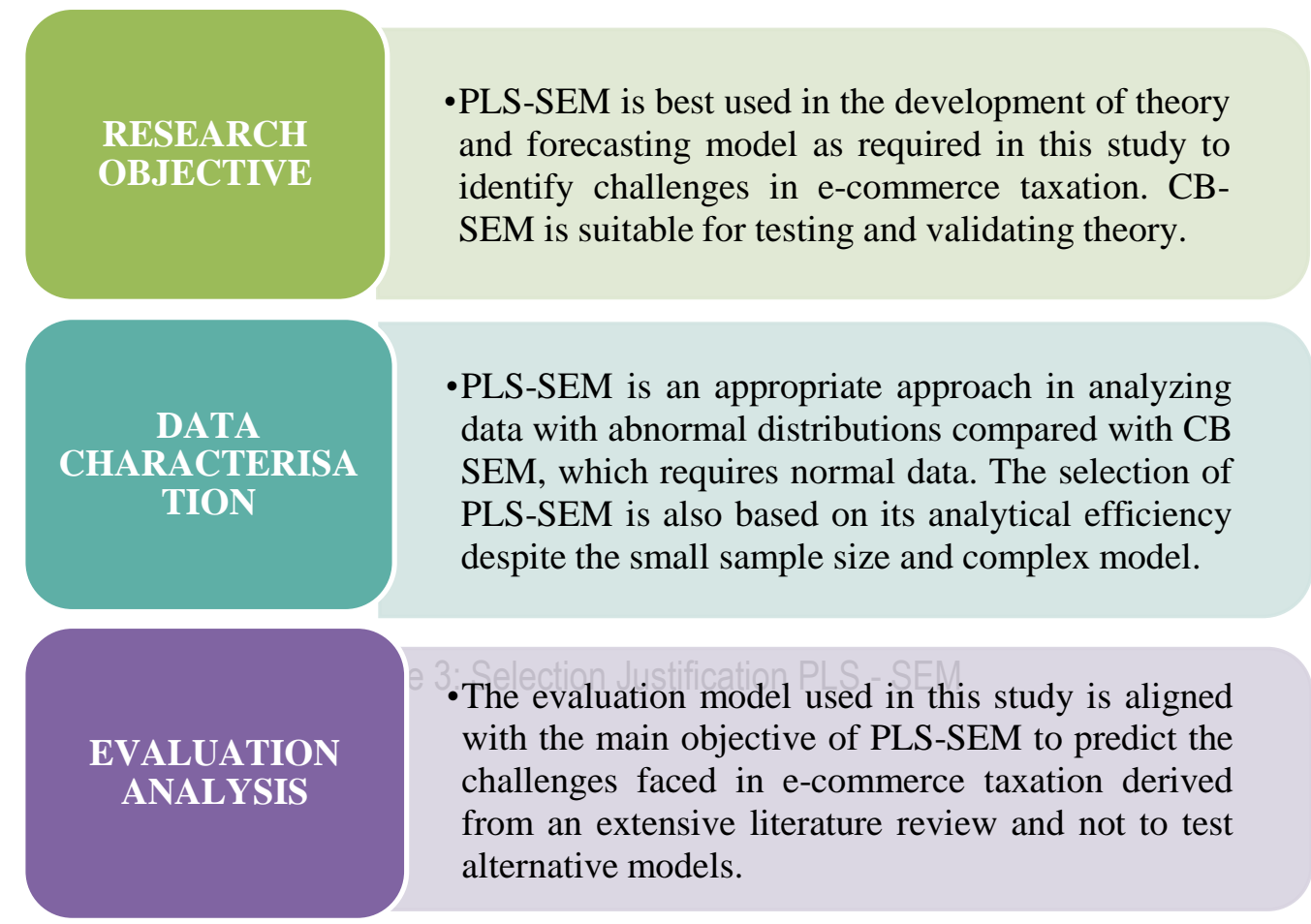

Figure 3 Compare between PLS-SEM and CB-SEM

The analysis data begin with the initial findings where the pilot test results are presented. These are followed by observations of the respondents' profiles and descriptive analysis of each construct. PLS-SEM analysis was performed using a widely adopted reporting structure as suggested by Hair et al. (2017). The PLS-SEM analysis begins with a measurement model for reflective constructs involving internal consistency (alpha and Cronbach composite reliability), convergence validation (indicator reliability and extracted average variance) and discriminant validation. Then, structural model analysis is performed by evaluating the determination coefficient, predictive relevance, measurement, and importance of the coefficient.

\section{Pilot Study Analysis}

The pilot study, an important element of investigating the reliability of the questionnaire before proceeding with further research, was conducted by examining the Cronbach's alpha reliability coefficient. In this work, a pilot study was conducted by sending 50 sets of questionnaires to officers involved in tax affairs at the IRB. Respondents were randomly selected from 476 officers, among which 27 were returned (equivalent to a response rate of $54.0 \%$ ). The total response rate of the respondents met the requirement to conduct a pilot study analysis as shown in Table 3. 
Table 3 Total Samples Based on Previous Studies

\begin{tabular}{cc}
\hline Researchers & Sample Size Suggestion \\
\hline Zikmund (2003) & 2550 \\
Cooper and Schindler (2003) & 25100 \\
Isaac and Michael (1995) & $10-30$ \\
\hline
\end{tabular}

Based on the reliability test performed using SPSS software as shown in Table 4, the Cronbach's alpha reliability value for each construct is in the range of $0.7-0.9$ similar to the value proposed by Tavakol and Dennick (2011). These results show that the instruments used are reliable. Detailed analysis results are reported in Appendix C.

Table 4 Reliability Analysis for Pilot Studies

\begin{tabular}{|c|c|c|c|}
\hline CHALLENGES & CRONBACH'S ALPHA (CA) & ITEM & $\mathbf{N}$ \\
\hline $\begin{array}{c}\text { TAXPAYER } \\
\text { IDENTIFICATION }\end{array}$ & 0.760 & 4 & 27 \\
\hline $\begin{array}{l}\text { INCOMPLETE } \\
\text { INFORMATION }\end{array}$ & 0.907 & 4 & 27 \\
\hline $\begin{array}{c}\text { PRODUCT } \\
\text { IDENTIFICATION }\end{array}$ & 0.877 & 4 & 27 \\
\hline $\begin{array}{l}\text { LACK OF AUDIT } \\
\text { TRACKING }\end{array}$ & 0.915 & 3 & 27 \\
\hline $\begin{array}{l}\text { LACK OF SYSTEM } \\
\text { CONTROL }\end{array}$ & 0.821 & 3 & 27 \\
\hline ELECTRONIC PAYMENTS & 0.756 & 4 & 27 \\
\hline
\end{tabular}

\section{Respondent Feedback}

Based on feedback from respondents consisting of officers involved in the taxation system in Malaysia, 81 of the 214 questionnaires distributed were received. This provides a questionnaire response rate of $37.9 \%$. A study conducted on the response rate of questionnaires based on the literature from several journals in 2000-2005 found that the range of non-response rates for individual responses was 3\%-91.2\% and organizational response rates were in the $10 \%-91 \%$ range (Baruch \& Holtom, 2008; Murillo-Luna, GarcésAyerbe \& Rivera-Torres, 2011). In addition, the number of samples still meets the minimum sample size of 10 times the regulation (Barclay et al., 1995), which shows that the minimum sample size should be equal to greater than 10 times the largest structural number directed at a particular construct in the model structure. As the maximum number of arrows pointing to the latent variables in this study is six (based on the six main challenges), the minimum sample size should be 60 samples $(6 \times 10)$. The next process is data filtering as proposed by Coakes et al. (2009) to ensure that the data in the questionnaires are complete. A total of 8 questionnaires were returned with more than $10 \%$ of items missed. Therefore, incomplete 
questionnaires were filled, and missing data were removed for further analysis.

\section{Normal Analysis}

Based on this study, the data normality test was performed even though the PLS-SEM analysis did not require that the data to be analyzed was normal. However, a detailed understanding of the data collected will ensure that the analysis results are more accurate (Hair et al., 2014) and the data are not extremely far from the normal distribution. Three measurement criteria are used to identify normalcy, namely, skewness in the range of $+/$ 1 (Field, 2014), critical ratio (CR) for skewness in +/-3 (Kline, 2015) and CR for kurtosis in +/-7 (Byrne, 2010). Based on the results of the normality test data summarized in Table 5 and the details shown in Appendix $D$, the maximum values for skewness, $C R$ for skewness and $C R$ for kurtosis are within the normal distribution range.

Table 5 Data Normalization Analysis

\begin{tabular}{lccc}
\hline NORMALITY TEST & VALUE REQUIRED & MAXIMUM & RESULT \\
\hline Skewness & $+/-1$ & -0.772 & Normal \\
CR for skewness & $+/-3$ & -1.376 & Normal \\
CR for kurtosis & $+/-7$ & -2.479 & Normal \\
\hline
\end{tabular}

\section{Descriptive Analysis}

Table 6 shows information on the breakdown of respondent profiles that provide feedback based on the aforementioned sample framework.

Table 6 Profile of Final Survey Questionnaire Respondents

\begin{tabular}{|c|c|c|c|}
\hline & Profile & Frequency & Percentage \\
\hline 1. & Gender & & \\
\hline$\bullet$ & Male & 57 & $83.19 \%$ \\
\hline$\bullet$ & Female & 16 & $16.81 \%$ \\
\hline 2. & Region & & \\
\hline • & South (Johor, Melaka, Negeri Sembilan) & 6 & $8.22 \%$ \\
\hline • & Central (Kuala Lumpur, Selangor, Pahang) & 19 & $26.03 \%$ \\
\hline • & East Malaysia (Sabah and Sarawak) & 20 & $27.40 \%$ \\
\hline$\bullet$ & $\begin{array}{l}\text { North (Perak, Penang, Kedah, Perlis, Kelantan, } \\
\text { Terengganu) }\end{array}$ & 28 & $38.36 \%$ \\
\hline 3. & Position Level & & \\
\hline$\bullet$ & Management & 5 & $6.85 \%$ \\
\hline • & Executive & 39 & $53.42 \%$ \\
\hline$\bullet$ & Support Staff & 29 & $39.73 \%$ \\
\hline 4. & Period of Service & & \\
\hline$\bullet$ & Less than 3 Years & 4 & $5.48 \%$ \\
\hline$\bullet$ & 3-7 Years & 16 & $21.92 \%$ \\
\hline$\bullet$ & $8-15$ Years & 16 & $21.92 \%$ \\
\hline$\bullet$ & More than 15 Years & 37 & $50.68 \%$ \\
\hline 5. & Involvement in Tax Service & & \\
\hline$\bullet$ & Less than 1 Year & 10 & $13.70 \%$ \\
\hline$\bullet$ & 2-4 Years & 18 & $24.66 \%$ \\
\hline$\bullet$ & 5-8 Years & 17 & $23.29 \%$ \\
\hline • & More than 9 Years & 28 & $38.36 \%$ \\
\hline
\end{tabular}


According to Table 6, the respondents consisted of 57 male and 16 female officers. The highest number of responses was recorded in the northern region with 28 officers, followed by eastern Malaysia (20), Central Region (19) and Southern Region (6). Among the respondents, executives provided the highest response rate with 39 people followed by 29 support staff and 5 IRB management. These results may be due to the executive and support staff being intermediaries and always transacting with dealers. Based on the feedback, most of the respondents are experienced due to the long period of service in the IRB and have substantial work experience in the tax system. This condition is evidenced by more than $50 \%$ having served the IRB for 15 years. Furthermore, 60\% of the respondents have been involved in the tax system for at least 5 years and only $14 \%$ for less than a year.

\section{Analysis of Structural Equation Model (SEM)}

Hair et al. (2017) explained that SEM is a multivariate technique that combines aspects of factor analysis and regression, which allows researchers to simultaneously study the relationship between measured and latent variables as well as between latent variables. The study model analysis involved formative and reflective constructs based on PLS-SEM. In this study, SmartPLS software is used to perform factor analysis The advantages of Smart PLS enable the study model to have formative measurements that are difficult to perform in CBSEM. Measurement models involving the reliability and validation of constructs and indicators refer to the recommendations by Hair et al. (2017). These measures involve verification factor analysis performed to test reliability, convergent verification and verification of discrimination of all items in the measurement construct.

According to the results generated through PLS-SEM, all constructs meet the convergent validity requirements as shown in Table 5. Although some items with external loading (outer loading) are less than 0.7 , such as PC2 and PP1 items, the researchers retained both items based on the explanation by Hair et al. (2017), where items less than 0.7 can be retained if AVE reaches 0.5 . In addition to convergence verification, internal consistency reliability values should be considered and met to maintain items in the model. Based on the values reported in Table 7, all constructs achieve acceptable values of more than 0.6 and 0.7 for internal consistency and reliability.

Table 7 Internal Consistency Reliability and Convergent Validity Result

\begin{tabular}{|c|c|c|c|c|c|}
\hline \multirow[b]{2}{*}{ CONSTRUCT } & \multirow[b]{2}{*}{ CODE } & \multicolumn{2}{|c|}{ Convergent Validity } & \multicolumn{2}{|c|}{$\begin{array}{l}\text { Internal Consistency } \\
\text { Reliability }\end{array}$} \\
\hline & & $\begin{array}{l}\text { LOADING } \\
(>0.7)\end{array}$ & $\begin{array}{l}\text { AVE } \\
(>0.5)\end{array}$ & $\begin{array}{c}\text { CR } \\
(>0.6)\end{array}$ & $\begin{array}{c}\text { CA } \\
(>0.7)\end{array}$ \\
\hline \multirow{4}{*}{$\begin{array}{l}\text { Taxpayer } \\
\text { Identification (PC) }\end{array}$} & PC1 & 0.804 & 0.598 & 0.855 & 0.772 \\
\hline & PC2 & 0.659 & & & \\
\hline & PC3 & 0.825 & & & \\
\hline & PC4 & 0.794 & & & \\
\hline \multirow{4}{*}{$\begin{array}{l}\text { Incomplete } \\
\text { Information (MR) }\end{array}$} & MR1 & 0.820 & 0.713 & 0.908 & 0.865 \\
\hline & MR2 & 0.906 & & & \\
\hline & MR3 & 0.761 & & & \\
\hline & MR4 & 0.883 & & & \\
\hline \multirow{2}{*}{$\begin{array}{l}\text { Product Identification } \\
\text { (PP) }\end{array}$} & PP1 & 0.609 & 0.558 & 0.833 & 0.728 \\
\hline & PP2 & 0.812 & & & \\
\hline
\end{tabular}




\begin{tabular}{|l|l|l|l|l|l|}
\cline { 2 - 6 } & PP3 & 0.720 & & & \\
\cline { 2 - 6 } & PP4 & 0.826 & & & \\
\hline \multirow{3}{*}{$\begin{array}{l}\text { Lack of Audit } \\
\text { Tracking (PA) }\end{array}$} & PA1 & 0.810 & 0.628 & 0.835 & 0.705 \\
\hline \multirow{3}{*}{$\begin{array}{l}\text { Lack of System } \\
\text { Control (KS) }\end{array}$} & PA2 & 0.817 & & & \\
\cline { 2 - 6 } & PA3 & 0.748 & & & \\
\hline \multirow{4}{*}{ Payment Method (PE) } & KS2 & 0.763 & 0.658 & 0.852 & 0.746 \\
\cline { 2 - 6 } & KS3 & 0.815 & & & \\
\cline { 2 - 6 } & PE1 & 0.858 & 0.695 & 0.901 & 0.853 \\
\cline { 2 - 6 } & PE2 & 0.819 & & & \\
\cline { 2 - 6 } & PE4 & 0.790 & & & \\
\hline
\end{tabular}

The analytical steps were continued by evaluating discriminant validation using the Fornell and Larcker (year) table. As shown in Table 8, the measurement model for reflective constructs has sufficient discrimination confirmation that all other diagonal elements of the construct are lower than the square root of AVE for each construct. Thus, Fornell and Larcker criteria were met, thereby confirming that the analysis of the measurement model for this study had a confirmation of discrimination that met the requirements.

Table 8 Confirmation of discrimination by Fornell and Larcker

\begin{tabular}{|lllllll|}
\hline & PC & MR & PP & PA & KS & PE \\
\hline PC & $\mathbf{0 . 7 7 3}$ & & & & & \\
\hline MR & 0.23 & $\mathbf{0 . 8 4 4}$ & & & & \\
\hline PP & 0.16 & 0.14 & $\mathbf{0 . 7 4 7}$ & & & \\
\hline PA & 0.34 & 0.20 & 0.11 & $\mathbf{0 . 7 9 2}$ & & \\
\hline KS & 0.53 & 0.21 & 0.19 & 0.48 & $\mathbf{0 . 8 1 1}$ & \\
\hline PE & 0.57 & 0.33 & 0.24 & 0.52 & 0.60 & $\mathbf{0 . 8 3 4}$ \\
\hline
\end{tabular}

The results of the measurement model using SmartPLS meet the required criteria. Therefore, the challenges in the implementation of $e$ commerce taxes as shown in Figure 4 can be confirmed through the analysis conducted. This result means that the 6 main challenges consisting of 22 items are the challenges faced by tax institutions in Malaysia in implementing ecommerce taxes. These findings help responsible officials to strengthen the country's taxation system. 


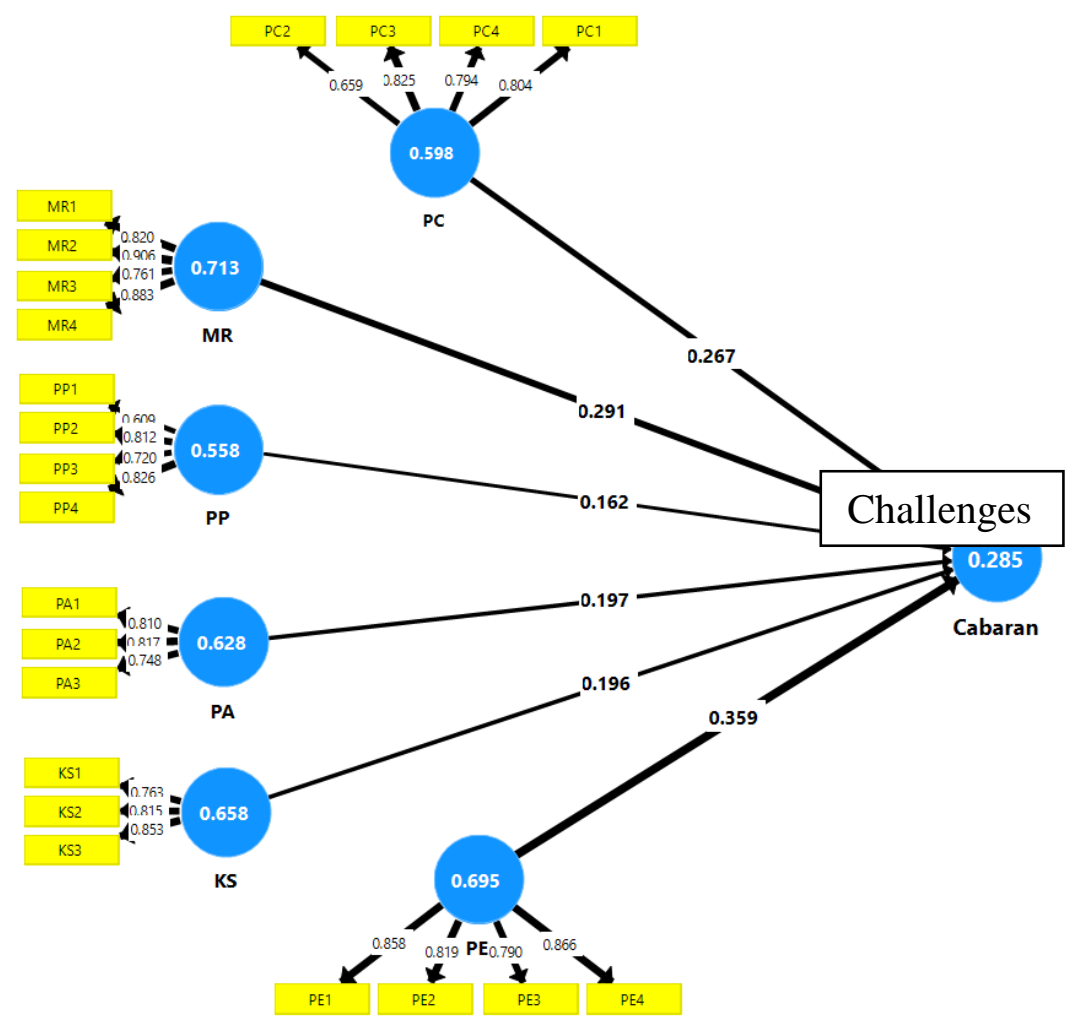

Figure 4 Path result

Analysis through PLS-SEM provides additional information to determine the major challenges faced by tax officers based on the value of the path coefficient from the analysis of
SEM (Hair et al., 2014) as shown in Figure 4. Based on the value of the path coefficient, the weighting percentage of each major challenge can be calculated and shown in Table 9 .

\section{Table 9 Order of Challenges by Weight}

\begin{tabular}{lcc}
\hline \multicolumn{1}{c}{ MAIN CHALLENGE } & PATH COEFFICIENT & PERCENTAGE (\%) \\
\hline Lack of system control & 0.359 & 24.37 \\
Incomplete information & 0.291 & 19.79 \\
Weaknesses of audit tracking & 0.267 & 18.13 \\
Product identification & 0.197 & 13.37 \\
Taxpayer identification & 0.196 & 13.34 \\
Electronic payments & 0.162 & 11.00 \\
& & 100.00 \\
TOTAL & 1.473 & \\
\hline
\end{tabular}


The major challenge faced was the lack of system control, which accounted for $24.37 \%$ of the total number of challenges encountered. Respondent officials believed that inadequate tax system facilities and infrastructure were major constraints in the implementation of ecommerce taxes. The second major challenge faced by officials was the incomplete information on the e-commerce transactions of person-run businesses, which accounted for $19.79 \%$ of the total. Officials stated that incomplete and inaccurate business information is a problem in imposing taxes on person-run businesses. The third major challenge was the weakness in audit tracking, which accounted for $18.13 \%$ of the overall challenges. Officers involved acknowledged the need for clear criteria in determining the products to be taxed to avoid confusion in tax implementation. The fourth and fifth challenges had almost the same percentage at $13.37 \%$ and $13.34 \%$. Both challenges refer to the nearly identical elements of product and taxpayer identification. The basis for resolving this challenge is to produce clear guidelines in determining the products and taxpayers involved. The last challenged faced by tax collectors is electronic tax payment, which accounts for $11 \%$ of the total challenges faced. Increasing computer literacy of business operators alleviate this burden for tax collectors in Malaysia.

With regard to the optimal tax standard theory proposed by Mankiw, Weinzierl and Yagan (2009), the formation of the tax system should be selected based on the ability to maximize the tax function itself but should look at the constraints or challenges that need to be faced in tax implementation. Thus, identifying the six key challenges that have been confirmed through a comprehensive statistical analysis can help the authorities, especially the IRB, to overcome these challenges and further improve the performance of the tax system in Malaysia (Suntoro \& Tjen, 2017; Patel, 2014; Low, Kabasunakatuba \& Sharma 2013). The basis of the optimal tax standard theory not only helps to identify the elements that need to be emphasized in the management of the ecommerce tax system but also considers the needs from the point of view of consumers who are taxpayers. The empirical information obtained from this study can guide officials in improving the effectiveness of tax collection on e-commerce transactions in Malaysia, thereby increasing the country's total revenue

\section{CONCLUSION AND SUGGESTIONS}

This empirical study successfully identified the challenges faced by tax implementation on e-commerce in Malaysia as confirmed through CFA. A total of 6 major challenges and 22 items were identified, which can serve as a reference for similar future studies based on the challenges previously reported by Suntoro \& Tjen (2017), Patel (2014), Low, Kabasunakatuba \& Sharma (2013), Chen \& Wang, (2010) Mohd Hanefah, Othman, \& Hassan (2006), Li (2000) and Pinto (2005). Based on the results generated through PLSSEM, all constructs meet the convergence validation requirements. In addition, all constructs achieve acceptable values of more than 0.6 and 0.7 in internal consistency and reliability. The analysis step is continued by evaluating discriminant validation using Fornell and Larcker tables, which show that measurements for reflective constructs have adequate discrimination validation, that is, all other diagonal elements of the construct are lower than the square root of AVE for each construct. The PLS-SEM analysis also provides additional information to researchers in identifying the major challenges faced in the implementation of e-commerce tax in Malaysia.

The primary challenge faced was the lack of system control, which accounted for $24.37 \%$ of the total. The inefficient control system being the basis of weakness in the tax system was also pointed out by Mosomi (2015), who said that good system management can increase the tax collection of a country. 
Therefore, to solve this problem, the IRB can strengthen its network of cooperation with interested agencies as one of the preventive measures to reduce the rate of fraud and tax evasion. This condition includes coordinating tax administration issues. Another solution is to establish strategic cooperation with external agencies such as the Malaysian Communications and Multimedia Commission. As a result of this collaboration, the LHDNM eCommerce division is able to obtain online merchant data to be used as a reference before further action is taken against taxpayers who try to avoid paying the mandated amount of taxes.

The second and fourth major challenges are the information on person-run businesses using incomplete e-commerce transactions, which account for $19.79 \%$ weakness in product identification and represent $13.37 \%$ of the overall challenge. Both of these challenges are closely related to the basic problem of incomplete information. Saputra (2020) suggests that measures to improve taxpayer behavior in e-commerce tax compliance can be implemented through the integrated behavior model approach, which outlines that incentives should be provided to those who comply in providing business information related to ecommerce transactions. Therefore, the IRB should provide an easily accessible platform and offer rewards to taxpayers who voluntarily update their business information.

The third challenge is the weakness in audit tracking, which accounts for $18.13 \%$ of the total challenge. Several redevelopments have been implemented to strengthen the IRB's operations as an agency that contributes key resources to the country through direct taxes, especially in strengthening the tax audit program (IRB, 2016). However, the IRBM can introduce other initiatives to curb tax leakage such as the introduction of tax audit, which is the inspection of business accounts and taxpayer's financial records to check whether taxes have been reported and paid in sufficient amounts. The level of compliance with tax laws and regulations should always be measured (Duke et al., 2013), improved and fully complied with to ensure that gaps in audit tracking can be avoided.

The fifth challenge is the identification of taxpayers, which accounts for $13.34 \%$ of the total challenges faced. As proposed by Zeng et al. (2012), strengthening the network of cooperation with stakeholders is one of the preventive measures that can be implemented by the authorities to reduce the rate of fraud and tax evasion. In addition, strategic bilateral cooperation with external agencies such as the Malaysian Communications and Multimedia Commission, Mynic, Exabytes and others, needs to be enhanced to address the problem. The result of this collaboration is that the IRB obtains the data on e-commerce person-run business for use as a reference before further action is taken against taxpayers who try to avoid paying the proper taxes.

The sixth challenge is the electronic tax payment constraint, which represents $11 \%$ of the total challenges faced. Despite an increase in the technology use by tax authorities, the evaluation of the quality of services delivered electronically is limited (Saha et al., 2012). Studies on the quality of information and services, and system usage and design are critical factors in the success of service delivery in e-commerce taxation systems (Saha et al., 2012). Therefore, the IRB needs to provide access and establish a more user-friendly taxation system to ensure that taxpayers can easily transact electronically.

Finally, considering the challenges presented in this study, the authorities can improve the taxation system and formulate highly comprehensive tax rules on e-commerce to identify potential tax revenues and reduce revenue losses at the national level. This study can also be used as a reference in identifying policies that need to be improved and continued. The proposals presented in this study should be practiced so that the robustness and accuracy of 
the e-commerce tax system in Malaysia can be

improved.

\section{REFERENCES:}

Abraham, A., \& Carceles Poveda, E. 2016. Tax reform with endogenous borrowing limits and incomplete asset markets. Society for Economic Dynamics, 1196, 1-25.

Agrawal, D. R. 2014. LOST in America: Evidence on local sales taxes from national panel data. Regional Science and Urban Economics, 49, 147-163.

Awang, Z. 2015. SEM made simple: A gentle approach to learning Structural Equation Modeling. Bangi, Selangor: MPWS Rich Publication.

Barclay, D., Higgins, C., \& Thompson, R. 1995. The partial least squares (PLS) approach to casual modeling: personal computer adoption and use as an Illustration. Technology Studies, Special Issue on Research Method-ology, 2(2), 285-309.

Baruch, Y., \& Holtom, B. C. 2008. Survey response rate levels and trends in organizational research. Human relations, 61(8), 1139-1160.

Basu, R. 2001. New criteria of performance management. A transition from Enterprise to Collaborative Supply Chain. Measuring Business Excellence, 5(4), 7-12

Berger, P. L. 1990. The sacred canopy: Elements of a sociological theory of religion. New York: Anchor Books.

Borkowski, S.C. 2002. Electronic commerce, transnational taxation, and transfer pricing: Issues and practices. The international Tax Journal, 28(2).

Byrne, B. M. 2010. Structural Equation Modeling with AMOS. Structural Equation Modeling (2nd ed.). New York: Routledge Francis \& Taylor.

Chang, T. L. 2002. Six Sigma: A Framework for Small and Medium Sized Enterprises to Achieve Total Quality (Unpublished doctoral dissertation). Cleveland State University,Cleveland, Ohio.

Chen, W., Wang, C., \& Wang, Y. 2010, Scalable influence maximization for prevalent viral marketing in large-scale social networks. Paper presented at the 16th ACM SIGKDD International Conference on Knowledge Discovery and Data Mining, Washington, USA, July.

Coakes, S. J., \& Steed, L. 2009. SPSS: Analysis without anguish using SPSS version 14.0 for Windows. New York: John Wiley \& Sons, Inc.

Cooper, D. R., \& Schindler, P. S. 2003. Business Research Methods (8th ed.). Singapore: McGraw-Hill Book.

Creswell, J. W. 2014. Research Design: Qualitative, Quantitative, and Mixed Methods Approaches. California: Sage Publications.

Davis, A., and Chan, P. 2000, Taxation of Internet commerce: Some potential international problems. Paper presentation at the Hong Kong Asia-Pacific Conference, October.

Field, A. 2009. Discovering Statistics Using SPSS. Statistic (2nd ed.). London: Sage Publication.

Foley, P., and Khoo, L.F 2000. International policies of e-commerce. European Business Review, 12(4).

Fornell, C., \& Larcker, D. F. 1981. Structural Equation Models with Unobservable Variables and Measurement Error: Algebra and statistics. Journal of Marketing Research, 18(3), 382-388.

Hadri, K. 2018 Malaysia negara ke-9 paling aktif media sosial, ke-5 paling ramai guna e-dagang. Astro Awani, Research News. Retrieved from https://www.astroawani.com/gaya-hidup/malaysia-negara-ke9-palingaktif-media-sosial-ke5-paling-ramai-guna-edagang-laporan-166998.

Hair, J. F., Hult, G. T. M., Ringle, C. M., \& Sarstedt, M. 2017. A Primer on Partial Least Squares Structural Equation Modeling. (2nd Ed.). California: Sage Publication.

Hair, J.F., Hult, G.T.M., Ringle, C.M., \& Sarstedt, M., 2014. A Primer on Partial Least Squares Structural Equation Modeling (PLS-SEM). California: Sage Publication.

Isaac, S., \& Michael, W. B. 1995. Handbook in research and evaluation: A collection of principles, methods, and strategies useful in the planning, design, and evaluation of studies in education and the behavioral sciences. San Diago: Edits publishers. 
Joe Duke, I. I., Kankpang, K., Emenyi, E., \& Efiok, S. 2013. Impediments of electronic commerce as a tax revenue facilitator in Nigeria. International Business Research, 6(6), 1-10.

Kline, R. B. 2015. Principles and practice of structural equation modelling. New York: Guilford publications.

Krejcie, R. V., \& Daryle W. Morgan 1970. Determining Sample Size for Research Activities. Educational and Psychological Measurement. 607-610.

Low, M., Kabasunakatuba, L. L., \& Sharma, U. 2013. The Challenges to Taxing E-Commerce: A Comparative Analysis for the Pacific. African Journal of Accounting, Auditing and Finance, 2(4), 334-359.

Mangione, T. W. 1995. Mail Surveys: Improving the Quality (Vol. 40). Sage Publication.

Mankiw, N. G., Weinzierl, M., \& Yagan, D. 2009. Optimal taxation in theory and practice. Journal of Economic Perspectives, 23(4), 147-74.

Ministry Home Affair. 2019. Definasi E-Dagang, Laporan Tahunan Lembaga Hasil Dalam Negeri.

Mirrlees, J. A. 1971. An Exploration in the Theory of Optimal Income Taxation. Review of Economic Studies, 38(2), 175-208.

Mosomi, N. A. 2015. Determinants of tax efficiency perceptions by domestic taxpayers in Kenya: The case of Nairobi. International Journal of Economics. Finance and Management Sciences, 3(5), 541-545.

Murillo-Luna, J. L., Garcés-Ayerbe, C., \& Rivera-Torres, P. 2011. Barriers to the adoption of proactive environmental strategies. Journal of Cleaner Production, 19(13), 1417-1425.

Nora Fauzana, Z., \& Noraza, M.U. 2018. The Impacts and Challenges of Electronic Commerce on Taxation.Paper presented at the International Conference on E-Commerce, October. www.icoec.my

Othman, Z., Hanefah, H., \& Bidin, Z. 2004. Taxation of E-Commerce: Determination of Permanent Establishment in Malaysia. Unpublished Manuscript.

Palil, M. R. 2010. Tax knowledge and tax compliance determinants in self-assessment system in Malaysia (Unpublished doctoral dissertation). University of Birmingham, Birmingham, United Kingdom.

Patel, S. H. 2014. Challenges of Value Added Tax on International E-Commerce in Electronic Goods and Services in Kenya. Research Journal of Finance and Accounting, 5(7), 139-143.

Pinto, D. 2005. 'Conservative' And 'Radical' Alternatives for Taxing E-Commerce (Part 1). Journal of International Taxation, 16(8), 14.

Saha, P., Nath, A.K., \& Salehi-Sangari, E. 2012. Evaluation of government e-tax websites: an information quality and system quality approach. Transforming Government: People, Process and Policy, 6(3), 300-321. Retrieved from https://doi.org/10.1108/17506161211251281.

Saputra, A. H. 2020. Improving e-commerce tax voluntary compliance behavior: An integrated behavioral model approach. In Public Sector Accountants and Quantum Leap: How Far We Can Survive in Industrial Revolution 4.0? Paper presented at the 1st International Conference on Public Sector Accounting, August, Jakarta, Indonesia.

Scally, A. 2004. Update to OECD model tax convention, February, Retrieved from http://www.kpmg.ie/services/tax/publications/taxarticles/2002/ModelTaxConvention

Smola, A. J., \& Bartlett, P. L. 2001. Sparse Greedy Gaussian Process Regression. Paper presented at the $13^{\text {th }}$ International Conference in Neural Information. Processing Systems, January. https://papers.nips.cc/paper/1880-sparse-greedy-gaussian-process-regression.

Suntoro, A. A., \& Tjen, C. 2017. The Challenges of Implementing Value-Added Tax On E-Commerce Transactions In Indonesia. Unpublished manuscript.

Tavakol, M., \& Dennick, R. 2011. Making Sense of Cronbach's Alpha. International Journal of Medical Education, 2, 53-55.

Vohra, R. 2004. Taxing E-Commerce Problems and Possible Solutions. Retrieved from http://www.asianlaws.org/projects/taxing_ecom.ht.

Zeng, Y., Guo, X., \& Huang, H. 2012. E-commerce tax collection and administration in China. Paper presented at the International Conference on Information Management, Innovation Management and Industrial Engineering, October, Sanya, China.

Zikmund, W.G. 2003. Business Research Methods (7th ed.). South-Western: Thomson. 